ISBN 978-93-86878-06-9

8th International Conference on Literature, Languages, Humanities and Interdisciplinary Studies

(LLHIS-17)

Kuala Lumpur (Malaysia) Dec. 14-15, 2017

\title{
"The Evolution of Indian Women Psyche: A Chronological Study of Women and Woman Writers in India"
}

\author{
Dr. S. Henry Kishore \\ Assistant Professor of English, Thiagarajar College, Madurai, Tamil Nadu, India \\ kishorehenry@gmail.com, +919894736432
}

\begin{abstract}
Modern Indian women amidst apparent change retain the basic roles. The patriarchal Indian society looks (down) upon women in their straitjacketed roles, but in the early Vedic period upto 300 B.C. women were held in esteem and respect. Moghul era pushed women to the lowest ebb. British Raj, in the nineteenth century awakened the slumbering nation from its stupor. Indian epics delineate various noble women. Women writers slowly emerged, during pre-independence era. The post independence India witnessed a spurt of writing by women writers of greater quality and depth. Their works reflect the influence of post colonial and feminist theories.
\end{abstract}

Keywords: Patriarchal Indian society - Vedic period - Moghul, British Era - Evolution of Women writers in English.

\section{Introduction}

According to the great revolutionary philosopher Karl Marx, "Social progress can be measured with precision by the social position of the female sex." (www.brainyquote.com). Women provide perennial interest, as a source curiously complex being. The image of the middle-class Indian woman has undergone a rapid change in recent times. Modern Indian women are now more articulate, modern in their dress and more exposed to different streams of learning. From Agriculture to Aeronautics many Indian women are active in professional and public life. Even though one could see apparent change; the basic roles and presumptions about women's world remain the same.

\subsection{Women as Fashionable Subject}

Virginia Woolf in her world-renowned essay A Room of One's Own asks, "Are you aware that you are, perhaps the most discussed animal (women) in the Universe?" (35). As she comments, women now form the most fashionable subject for any discussion. Women have been at once the centripetal and centrifugal force for many creative artists. In India they have been the most idealized, idolized and canonized image in art, literature, sculpture and religion. The artists have exposed only their external physic but none cared to explore and express their psyche and the inmost passions of their mind. It was only in the wake of the feminist movements in the 20th century that writers thought of exploring the feminine minds.

\subsection{The Purpose of This Research Article}

This research article explores how the patriarchal Indian society looks (down) upon women and the straitjacketed roles it has defined for them, and also the historical evolution of Indian women writers in English. The realities of women's lives have been camouflaged and rendered invisible, and the image one chiefly gets is ambivalent. Indian men in their literary works usually tend to see woman from two extremes - either as a deified 
woman - Shakti or Devi or as a disgraced one - Devadasi and she has rarely been portrayed as a real living human being with ideas and emotions like those of a man.

\section{A Chronological Study on the Condition of Indian Women}

\subsection{From the Vedic Period}

A.S.Altekar in his book The Position of Women in Hindu Civilisation claims "the status of women is one of the best gauges of the spirit of a civilization, its excellencies and its limitations" (9) and particularly the status of women in India is tagged to the peculiar set up of our society. Right from the early Vedic period upto 300 B.C. women were held in esteem and respect. They enjoyed relatively high position in Indian society. The Vedic age also produced at least a score of eminent female scholars, poets and teachers and a number of hymns included in The Rig Veda, composed sometime between 1500 B.C. - 900 B.C. were attributed to women. In such a context Ashok Kumar rightly points out:

Women have always made a very significant contribution to their societies, but a patriarchal conspiracy has prevented women's contribution from receiving its due recognition. The reason is that the society's legitimating myths, the creation of written historical records and the production of authoritative self-knowledge have all been enterprises, controlled by males (7).

\subsection{In the 5th Century}

In the fifth century B.C. the nuns of Buddhism sang songs in praise of Buddha. These poems reverberate with a strangely modern note and the exultation in them reveals the happiness of breaking from the cramping bonds of an irksome domestic routine and the joy of self-expression. But the position of women deteriorated at length. Vern L. Bullogh records in his book The Subordinate Sex: "By the time the first Hindu Law codes emerged around 100 A.D; however, women had lost more ground vis-a-vis to the male" (230).

\subsection{Hindu Law Code}

The Hindu Law codes were based on sacred scriptures believed to be divinely inspired and unalterable. The earliest and most famous of these laws was Manusmrti. Manu, the codifier of ancient Hindu Law defined the proper societal role of a woman, perpetuating the dependant role for her. It was these laws which clearly demarcated the position of women and formulated codes for the tutelage of the girl child. Scholars record that his work Manava Dharmasastra or Manusmrti was the earliest that dealt with social philosophy, where he states that: "Her father guards her in childhood, her husband guards her in youth and her sons guard her in old age. A woman is not fit for independence" (Wendy Doniger 197). There are also parts of the codes which glorify and honour women, but whatever dignity or honour a woman enjoyed, the book reveals that she had the greatest prestige and dignity with no real power. Manu favoured only the domestic and religious education for woman. He also favoured the training in music and dance to the woman in order that, she may be able to please her man. Other law givers generally reflected Manu's biases.

\subsection{In the Medieval Period}

In the medieval period from ninth century to eighteenth century devotional Hinduism swept through India and it gave space to people on the margin, such as women, lower castes and outcasts. Women powerless and silent in many domains of community life, found strength in their sense of the divine and their own voice in poetry and songs. One could find saint poets like Akka Mahadevi, Andal, MiraBai, and Karaikkal Ammaiyar who had left a set of powerful poems expressing their love for the divine. All the aforesaid examples clearly reveal to us that the expressions were spiritual and nowhere do we get a glimpse of the social status of the women of that period and mental condition of their contemporary women. 


\subsection{During Moghul Era}

The fall in the status of women further has been attributed to the Muslim invaders.It was the Moghul era which pushed women to the lowest ebb. The status of women went down. Education for women was stopped and they became the victims of evil practices like child marriage with the attendant fall outs. The purdah system came to be established in this period even within the four walls of the joint family homes. Within the family, woman's right to rule the household was recognized, but she had to rule for the benefit of her husband. Women were not usually seen at public ceremonies and were accustomed to live in proper seclusion. Since no family could have two authorities, naturally the woman had to submit to her husband. Surely it was the arrival of the British which changed the scenario.

\subsection{During British Era}

The entry of the British Raj, in the nineteenth century awakened the slumbering nation from its stupor. The encounter with the West geared up the Indians into activity and self-realization and many radical changes occurred in the social and political sphere foregrounding the issue of women's education. The few educated women who wrote, conformed to the idealized images of the female in Indian society as mediated by religion, law and social practice. Within these boundaries arose a literature of beauty and sensitivity, but not one that articulated the writer's identities beyond gender stereotypes. The growth of women's education in the nineteenth century made the few but increasingly vocal, of the voice of women writers of the time - actively aware of women's roles, work and status.

\section{State of Women in Indian Literature}

So far the women's studies in history has been traced- now passing on to women as shown in literature, reflects the lives of women through the writings of men, and a few women now and then, about which Annie Besant exclaimed:

Literature can show no grander typing of womanhood than are to be found in the great epic poems of India. The types of Indian women sketched in by the master hands from noble models and writing in a few heroic figures reflect all that is at once strongest, sweetest, most lofty and most devoted in humanity. (Andal 9)

\subsection{Women in Indian Epic}

Though great epics like the Ramayana and the Mahabharata delineate various noble women, there seemed to be a trace of dichotomy inherent in Indian thought. This dualism portrayed woman either as a sensual, secular creature like Surpanaka or as a devoted wife and mother like Sita. It is considered that Indian women have been pictured as loving wife and tender mother and have been extolled or appreciated for this quality more in India than anywhere else. All such views were the opinions of men, the way they looked at women. These views rarely reflected what women themselves thought or felt about them. They had been mute all along, which is clear from this phrase: "Those from whom come no lesson, no instruction, are women and eunuchs" (Vern.L.Bullogh 250). This statement reveals that the life creating, second sex had been a silent majority. The voice of women heard sporadically, revealed that they were destined to remain in the periphery. Women as writers emerged very late in Indian literary history.

\subsection{Women in Poetry}

Despite the denial of public presence, Indian history shows how women, of the past have left their mark, sometimes faint but strong, in the form of poetry. The earliest recorded poetry by women in India was by Buddhist nuns of the sixth century B.C. The poems by these nuns stand as testaments to these women's joys, at finding freedom from the drudgery of everyday life and at achieving not merely social but spiritual liberation. Quite different from these spiritual perceptions are Tamil poems by women of the Sangam period (150B.C.250B.C). The poems reflect their ideals of self-worth which seemed to be confirmed wholly to the demands of 
warfare made on their men folk. Women's writing became scarcest as society became more rigid.Women were pushed to the periphery by a male-dominated society, making education less accessible to them.

\section{Evolution of Indian Women Writers}

\subsection{Pre-Independence Era}

In India women writers slowly emerged, starting from Torulata Dutt (1856-1877) who dealt with the archetypes of Indian womanhood like the mythical Sita and Savitri. Other writers of importance include Rajlakshmi Debi, her work The Hindu Wife or The Enchanted Fruit (1876) raised a banner of revolt against the prevailing social conditions. Krupabai Sathianandhan's (1862-1894) Kamala: A story of Hindu wife (1894) and Saguna: A story of Native Christian Life are autobiographical. Pandita Ramabhai Saraswati was hailed for her works which laid the foundation for women's liberation in India. Swarna Kumari Ghosal, elder sister of Rabindranath Tagore, was a novelist, poetess and playwright. Her two novels are An Unfinished Song (1913) and The Fatal Garland (1915). Cornelia Sorabji (1866-1954), the Oxford educated lawyer, fought for the cause of women, especially widows and women in purdahs with a spirit of adventure and missionary zeal. She is mainly famous for her three important works, Love and Life behind the Purdah (1901), Sun-Babies in the child life of India (1904) and Between the Twilight (1908).

Though not a novelist, Sarojini Naidu, the Nightingale of India, holds a place of prominence in the Indian literary horizon as a poetess. Women in most of the early novels are essentially Indian in sensibility, endowed with the traditional feminine qualities of sincerity, love and resignation. These writers of the first generation portrayed women in the traditional mode. Under the influence of the popular British writers, these women's writings tended to be imitative, while some focused on the romantic idealization; others wrote with a reformative zeal. On the whole, these women writers wrote with a reformatory spirit and an intense sociological motive. Hence there was no room for anger, irritation or tension in their work, but care and concern for the suffering Indian women.

\subsection{Post Independence Era: First Generation}

The post-independence India witnessed a spurt of fiction writing by women writers of greater quality and depth. The period between 1915 and 1950 had not produced any significant women writer. Consequently, there existed a clear gap of thirty-five years between the post independence writers and their forerunners. After a lapse of three decades the second generation of women writers attempted to project women as the central figure and have succeeded in presenting the predicament of women more effectively. These women writers have given a distinct dimension to the image of woman in the family and society. They had successfully portrayed the reactions, responses, problems and perplexities and the complex working of their inner selves and their emotional involvement and disturbances.

\subsection{The Second Generation}

Among the women writers of the second-generation Kamala Markandaya, Anita Desai, Ruth Prawer Jhabvala and Nayantra Sahgal occupy the foremost position in the literary field. Shobha De, Shashi Deshpande, Bharati Mukherji, Gita Hariharan, Rama Mehta, Meena Alexander, Arundhati Roy, Shanta Rama Rau, Namita Gokhale, Uma Vasudev and Jai Nimbkar are other prominent novelists of the present era. A brief sum up of the themes and techniques of the most prominent novelists would give us an idea of the present trend in Indian Writing in English.

To start with, Kamala Markandaya has secured a firm place in the literary circle. She has dealt with the problem of subsistence. Her novels, Nectar in a Sieve and A Handful of Rice deal with the plight of the poor people whose lives are an unending struggle for existence. In her novels one could find the traditional intimacy with Mother Earth since the fortunes of these rural characters are linked to fertility or sterility of the land and the people. Also Oriental in cultural heritage and occidental by habitation, Markandaya seems to be familiar with the interaction of the two cultures and the resultant identity crisis. Her concern with the growing impact of 
modernity on the basically traditional Indian society is evident in all her novels. Kalpana highlights Kamala Markandaya's portrayals:

She does not create a woman's world, but rather presents a real world. Mothers in her novels, define themselves by a set of relationships and modes of conduct, within a socio-cultural framework. She confronts women in a conservative society who are tossed between tradition and modernity - the twin horns of dilemma. (31)

She points out in Nectar in a Sieve how the emancipation of the Indian woman has been seriously hampered by the distortions of and imbalances in the economic and social order. Her stories mostly are narrated with precision and directness and she uses irony and imagery sparingly.

Ruth Prawer Jhabvala is variously described as inside outsider and outside insider. Born to a German-Polish parents, she married Cyrus Jhabvala, a young Parsi architect. Her creative urge found its artistic expression during her stay in India. She had written eight novels and had also published a few collections of short stories. She concentrated on the milieu familiar to her, the middle and upper middle class Indian society. Her fictional world is pervaded by domestic atmosphere and deals with familial themes. She often turns to the theme of the interaction between two cultures namely European and Indian. Her keen observation and awareness of life in Indian society, combined with her critical acumen result in the authentic portrayal of the day-to-day life of individuals in different predicaments. Jhabvala is especially aware of the position of women in Indian family and her novels portray the change that is brought in her attitude in the changing cultural context. Madhuri in her Esmond in India is one such character. Her other novel are Get Ready for Battle, Nature of Passion, To whom She will, Heat and Dust. The titles of these novels testify the Indianness of her novels and reveal her understanding of and interest in Indian culture. Though Jhabvala maintains the tone of the objectivity and sticks to straightforward narration, one can find cutting irony and social commentary in her novels.

Anita Desai broke a new ground in the world of Indian English fiction by shifting the emphasis from the external to the internal world. She created a world of her own which she filled up with extraordinarily sensitive beings. Her novels delineate the inner lives of hypersensitive women who are in eternal quest for meaningful life. Many of her characters find the real world too harsh, difficult, unpleasant and also too complex. They withdraw from reality into their inner world and search there for ways and means of living through this hostile world.

The general problem in the novels is of self-consciousness of the characters and the recurring theme is selfawareness and self-identity. In her first novel, Cry, The Peacock, Anita Desai reveals the grim psychological battle fought in the mind of Maya. Voices in the City, Bye-Bye Blackbird, Fire on the Mountain, Where shall we go this summer? and Clear Light of Day are her other novels. She states that: "Writing to me is a process of discovering the truth - the truth that is nine-tenths of the iceberg that lies submerged beneath the one-tenth visible portion we call reality" (Anita Desai 12).

She stands as the first Indian-English novelist, who views life primarily from an existentialist point of view. Most of her novels are revealed through interior monologue. She uses the images of birds to depict the inner longings of the women characters. Her prose reaches poetic heights in many places. The language is distinct in style and imagery. There is also compatibility between narration and narrative technique.

Nayantra Sahgal has established reputation both as a journalist and as a novelist. She has six novels and two autobiographies to her credit. She presents an authentic picture of India after independence. Jasbir Jain described Sahgal as "one of our best socio-political novelists today" (140). However, her absorbing concern with politics is not divorced from humanistic concern. Sahgal is a champion of individual freedom which is manifest in varied forms in her novels. She writes sensitively of the way women suffer owing to sexist bias in a patriarchal set up. She shows the need for a new morality in which a woman is treated as man's equal and the relationship is to be cemented with mutual trust, love and understanding. Storm in Chandigarh, The Day in Shadow, Rich Like us, A Time to be Happy. Nayantra Sahgal makes a close and sensitive study of the sufferings of the women 
belonging to the elite class and shows how they refuse to remain bound to the subordinate roles ascribed to them, trying to defy traditional norms in search of emancipation.

Bharathi Mukherjee and Gita Hariharan discuss the moral dilemma that women face, in their works. Rama Mehta and Meena Alexander are known for realistic portrayals and authentic sociological study. Shobha De is known for her frank narration of incidents, her focus being the elite women of India. Arundhati Roy joins the above group in the truthful portrayal of the plight of women in society and their marathon struggle for seeking the sense of 'identity' in a male dominated conservative framework.

\section{Conclusion}

A critical appraisal of these women writers explicitly reveals that the recurrent themes handled by them are the existing condition of women, marriage, family ties, motherhood and tradition and above all the patriarchal domination, which is very much alive. Their works reflect the influence of post colonial and feminist theories. Thus women's writings with all its variety has been moving to a dimension, where one can find them asserting themselves. This is because of the emerging of a new concept, women.

\section{References}

[1] Altekar, A.S,. The Position of Women in Hindu Civilisation. New Delhi: Motilal Banarsidass, 1962. Print. 14

[2] Andal, N.Women and Indian Society. Jaipur: Rawat Publications, 2002. Print.

[3] Bullogh, Vern.,The Subordinate Sex - A History of Attitudes Towards Women. New York: Penguin, 1973. Print.

[4] Desai, Anita.Voices in the City. New Delhi:Hind Pocket Books, 1968.Print.

[5] Doniger, Wendy, The Laws of Manu. New Delhi: Penguin Books India Ltd, 1991.Print.

[6] Jain, Jasbir.Gendered Realities, human spaces: The Writing of Shashi Deshpande. New Delhi: Rawat Publications, 2003.

[7] Kalpana, R.J.Feminist Issues in Indian Literature: Feminism and Family. New Delhi: Prestige, 2005. Print.

[8] Kumar, Ashok. Ed. "Women in India: Retrospect and Prospect", Women in Contemporary Indian Society. Vol. 1. New Delhi: Anmol Publications, 1993. Print.

[9] Marx, Karl. (n.d.). BrainyQuote.com. Retrieved November 8, 2014, from Brainy Quote .com Web site: http://www.brainyquote.com/quotes/quotes/k/karlmarx 384275. html

[10] Woolf, Virginia. A Room of Ones Own. New York: HarcourtBrace, 1975.Print. 